\title{
Performance Appraisal System: New Horizons
}

\author{
Mr. Parth I. Chhabra \\ Research Scholar, P.G. Department of Business Studies, Vallabh Vidyanagar-388120
}

*Corresponding Authors: Mr. Parth I. Chhabra, Research Scholar, P.G. Department of Business Studies, Vallabh Vidyanagar-388120, India

\begin{abstract}
Performance Appraisal is the regular and systematic evaluation, reviewing employees performance on the job with the respect to the continues improvement and overall development. As it a planned activity which is carried out, on the basis of which Promotion, Demotion, Termination, Transfer and Suspension orders are decided so on.

Purpose: The Study provides an exclusive view of the New Horizons and Trends developed in the Performance Appraisal System which can be adopted by the Industrial, Manufacturing and Service sector for the overall effectiveness of the employees as well as employer.

Methodology: The descriptive study is done with the help of existing past literature on the impact of performance appraisal and the quality issues prevailing prepared from journals, articles, books, websites, etc.

Results: It was revealed that most of the sector adopted Traditional methods instead of Modern methods. As several effective New trends can be adopted in this modern world for the overall development of employee and strengthening the employer-employee relations.
\end{abstract}

Keywords: Performance Appraisal System, Trends, Horizons.

\section{INTRODUCTION}

The term Human Resource means the sum of the knowledge, skills, abilities, creative, talents, competencies and aptitude of an organization's employees, as well as the perspective, beliefs, thoughts and actions. These qualities can be utilized by the organization again and again for improving the working capacities of the work place and positive output. As Human Resource is like a Natural Resource and so it should be treated \& utilized as if its natural resources. Human Resource is also known as Human Assets, Human Capital, Manpower, and Labor which widely shows the Physical abilities and capabilities of employees. It is though a wider term to express but it displays the clear idea about the employee's competence, skills and values. (Rao, 2014)

The New trends have given a newer rise to the performance appraisal system, despite many research has been so far done in this area by the behavior scientists, but the newer trends are yet to be explored in the deeper. In the Human Resource Management the most sensitive and prevailing area nowadays is Performance Appraisal System. As the man is a social and complex animal, it is important for him to get aware of his potential capabilities and its achievement level, which boost him all the time and keep him motivating. Here we are talking about the continually improving of the appraisal system. Its effectiveness has provided a unique dimension. Performance Appraisal system is not merely to judge and appraise the employees once in a year but to instigate the energy within themselves and turn the employees towards motivation. Therefore a sound appraisal system is called backbone of employee's motivation and company's well being. (Bhatia, 1981)

Here in this article, in the terms of theory, the indication regarding the new trends and latest horizons are being adopted by many organizations and which are the new methods of performance appraisal are mentioned with the traditional ones. Employees appraisal should be discussed practically and improving steps should be taken for continues improvement of present conditions rather to ignore the existing ones. 
As performance appraisal is the burning issue nowadays associated with appraisal system, its importance arises from the current business environment, which is marked up for the achievement of organizational goals as well for greater influence on the superior-employee relationships. (Chen, 2012)

So far as appraisal is concerned, it is important and aims at challenging against the employees in the organization to avoid the doubts of favoritism and mal-practices. It provide greater help in taking important decision regarding promotion, appreciation, recognition, increments and sometimes demotion or transfer orders too are decided upon it. It also helps in decision making regarding the training \& development for the employees and selection, recruitment process in the organization. It provides greater assistance in developing \& improving employee-employer relations.

Now after the New trends of appraisal it works as an open system rather than working traditionally.

Let's study the Performance appraisal methods with some new trends taking place in the enterprise.

\section{Methods of Performance Appraisal}

\begin{tabular}{|l|l|l|}
\hline & Traditional Methods & Modern Methods \\
\hline 1. & Ranking Methods & Management by objectives (MBO) \\
\hline & Paired Comparison & 360 - Degree appraisal \\
\hline & Grading Method & Critical Incident Method \\
\hline & Forced Distribution Method & Assessment Centre \\
\hline & Checklist Method & Behaviorally Anchored Rating Scales \\
\hline & Essay Method & Balanced Scorecard \\
\hline
\end{tabular}

While we all know that Traditional methods only displays the characteristics or traits like dynamism, potential to motivate, creativeness, Initiative and leadership skills. As this method is based on the job description and job specification. (Rao P. S., 2014)

The Modern methods measures various accomplishments of the employees, their evaluation, sales turnover, number of customers, number of units sold, number of complaints solved which the most important aspect of this new method.

\subsection{Management by Objectives}

The concept of management by objectives was found by Peter F. Drucker in year 1954. Many such improvements were brought out by George Odione, Humble, Valentine and other such have developed such a perfect concept and made it more acceptable for the companies globally as a perfect appraisal technique. As some companies which have implemented MBO had come with a fruitful and positive results.

Briefly the concept of MBO is where the subordinate and superior of an enterprise jointly come together and agree upon working on the common goals of the enterprise, defining each ones their respected responsibilities according to their specialized area and afterwards coming together for the assessment of the work contributed by each member of team. Following are the steps in the MBO process.

$>$ The first foremost step is to formulate and set the initial goals which the individual subordinate has to attain himself. In many of the organization the superior sometimes establish the goals for his subordinate or sometimes both superior-subordinate come together for their desired goals to be accomplished.

$>$ The second step includes the setting standards for the subordinates within the stipulated time, and they should know that what work has been done before, what has to be done and what is to do now.

$>$ The third step is the evaluation step in which the evaluator is appointed and evaluator evaluates the goals which were set before are met with the actual goals, sometimes goals also over exceeds too. After doing this, the decision regarding needful training for the subordinates are also taken. 
$>$ In fourth step the new strategies, new plans and new goals are framed so to overcome the attainment of previously set goals. At this time, superior and subordinate come together in setting new goals and new plans with a change in present ones, which can successfully help in attainment of the determined goals. This process is repeated again and again. (Ashwathappa, 2010)

\subsubsection{0- Degree Appraisal}

"This 360-Degree appraisal technique is understood as a systematic collection of performance data on an individual or group, derived from a number of stakeholders- the stakeholders being the immediate supervisor, team members and customers". (Aswathappa, 2010). The study on employees competencies identified that there are 4 parameters to assess 360- Degree Appraisal system like selfassessment; immediate supervisor assessment; subordinate assessment and peer assessment. (Horng, J. S., Hsu, H., Liu, C. H., Lin, L., \& Tsai, C. Y., 2011) . The 360- Degree appraisal depicts that the employee should be assessed with all the sides \& angles multiple times so that he doubts regarding the biasness, prejudice and favoritism is removed completely. This 360-degree appraisal helps in making the employee feel more and more accountable towards his customer and clients. As it is a multi-rater approach which helps in identifying the talent, potential skills and team-building skills of a employees. So it called an overcoming appraisal technique against the traditional approach of performance appraisal.

Further the firms take long time to decide a rater and train him, design the questionnaires, and assess the data collected. Here honest and unbiased reviews are required for the growth of a employee. Personal differences, views and prejudice should be avoided during this technique.

\subsection{Behaviorally Anchored Rating Scales}

Behaviorally Anchored Rating Scales are said to be the rating scales which include range of many statements from least to the most eligible ones describing the behavior of the ratee into it and marking them accordingly. It is also called behavioral expectation scale.

The features of Behaviorally Anchored Rating Scales (BARS) are as followed:

$>$ Here the areas of performance are to be identified and assessed first and stated properly by the people using this scale.

$>$ The scales are anchored properly by the description of actual job with the specific performance levels. Here the rating scale is set and afterwards according to the behavior it is anchored and accurately defined.

$>$ The behavior of the employees is assessed from all the possible dimensions relevant to the job as BARS are tailor-made for the job.

$>$ The raters are actively interested in the development process and are practically involved in this activity against the commitment of final output

\subsection{The Balanced Scorecard}

This concept was first developed by Robert Kalpan and David Norton. The concept links between the customer, strategies, learning, processes and financial performance. Its process includes product development and service development which are crucial in dealing with customer satisfaction and loyalty. As Customer value creation is done by the customer satisfaction, which drives the firm towards wealth creation and goals achievement.

There are some of the steps to be followed for successful implementation of balanced scorecard for performance appraisal system.

$>$ Convert the enterprise goals on the scorecard for clear objectives.

$>$ Certain guidelines should be stated in order to get the insights for the achievement of set goals.

$>$ Cascading balanced scorecards should be done so that the bottom level employees should get to know about their work aligned with the higher level employees and their set goals. 
$>$ For the achievement of goals the employees must be accountable to their superior at what extent they have achieved the goals and what are their failures or what work has been left unaccomplished.

Motivate the employees for improving their performance.

$>$ As balanced scorecard is continues loop activity to which management should make efforts for continuously improving the plans \& strategies based on the feedback and feed-forward basis.

\section{From Traditional To MOdERn APPROACH}

There is a tendency of us humans to move on from old to new horizons, same is the case with traditional Vs modern methods, as traditional approach is losing its importance day by day and on the other hand the enterprise is accepting the modern methods. The common concepts and trends which appraise the employees on the 'Merit-based rating' system has become very outdated; rather performance appraisal is given to the employees on the basis of work done by him.

More stress in now given on the potential capabilities of the employee rather than his personality. This initiates the growing concept in the minds of management which take them towards the on time goal accomplishment. MBO is though a theoretical concept acceptable by all but when it comes to performance appraisal it becomes ABO i.e. Appraisal by Objectives. Where mutually agreed goals are present the employees are more competent and they are more stranded towards their set goals, as this is the preferred method nowadays. As this approach plays a crucial role in goal setting and overcoming the loopholes \& weakness of old approach, this approach helps in developing new performance goals and achieve determined target.

It is considerably very true that ample amount of time and efficient managerial skill is like required investment, but more over motivation and development of employees is the prime need for the effective performance appraisal system. The organizations which had adopted the personality traits, have turned themselves and adopted the behavioral traits like relations with subordinates, relations with superior, relation with employees, relation with customers, relation with colleagues. This attitude should be adopted and pursued further for task achievement.

The process of appraisal involves judgement, this judgement is the foremost task done by the rater at the time of appraisal. Sometimes there comes a hurdle in between the positive response and so the unseen changes take place in the appraisal system. The effectiveness of appraisal system depends on the individual, but how the community reacts to the appraisal system is more valuable.

\section{CONCLuSion}

The major conclusion of this study is towards displaying the new horizons of Performance appraisal system. It has also highlighted necessary steps and changes for the effective appraisal system and practices. Now major focus was on the development of newer appraisal techniques and their potential benefits which make appraisal system stronger than the old approaches. Emphasis was led on the objectives, set goals, perception, potential, training \& development, motivation, employee's behavior, growth. As Performance Appraisal is unavoidable task because without its presence, no decisions regarding the On job employees can be taken. There is a need of creating awareness regarding the new methods of performance appraisal so that the old methods are avoided and new efficient methods are accepted.

If appraiser and appraise come together and work on the performance appraisal system then there will be avoidance of doubts, then the probability of mistakes or bad appraisal system will be diminished automatically. Appraiser appraise mutually identify the problems, work on them, can overcome it and come to the better positive results at the end. The feeling of frustration and anxiety would be vanished by joining the hands of both the parties i.e. rater- ratee. Together if both of appraiser- appraise join hands then many such problems of enterprise would be solved without any hassle, employees will divert towards qualitative work rather than avoiding the work load.

In this study new methods with their respected useful steps are mentioned in a detailed manner, moreover it displays that how far this newly developed appraisal methods are efficient than the previous ones. BARS, Balanced scorecard, 360- Degree appraisal, MBO are some of the modern 
methods which create a significant remark for the notable growth of the enterprise as well of the employees too. Performance appraisal system should be designed in such a way that it creates a fair \& positive impact on the minds of employees.

It is understood that benefits of performance appraisal system could not be adopted straightly, it is the fair practice by the management as well as constant judgement by the superiors which promote a healthy and honest appraisal system for all. The management should adopt a practice of not to demotivate and discourage the employees by pointing out their faults \& flaws, rather they should help them in discussing and overcoming their problems \& remove the faults. Here main focus is on effective implementation of new methods which promotes the better growth of enterprise. Performance appraisal system is itself is an art and science designing new methods with the latest trends in it, which gain importance for the whole enterprise. Future trends should always be welcomed and adopted if they are beneficial for the betterment of the enterprise.

\section{REFERENCES}

Ashwathappa, K. (2010). Human Resource Management (6th ed.). Tata Mc Graw Hill Education Private Limited .

Aswathappa, K. (2010). Human Resource Management (6th ed.). Tata Mc Graw Hill.

Bhatia, S. K. (1981). Trends in Performance Appraisal. Indian Journal of Industrial Relations , 17 (1), 111-120.

Chen, J. a. (2012)._Are — standardized performance appraisal practices' really preferred? Chinese Management Studies, , $4(3), 244-257$.

Horng, J. S., Hsu, H., Liu, C. H., Lin, L., \& Tsai, C. Y. (2011). 'Competency analysis of top managers in the Taiwanese hotel industry'. International Journal of Hospitality Management, , 30 (5), 1044-1054.

Rao, D. P. (2014). Essentials of Human Resource Management and Industrial Realtions. Himalaya Publishing House Pvt. Ltd.

Rao, P. S. (2014). Essentials of Human Resource Management and Industrial Relations (2014 ed.). Himalaya Publishing House Pvt. Ltd.

\section{AUTHOR'S BIOGRAPHY}

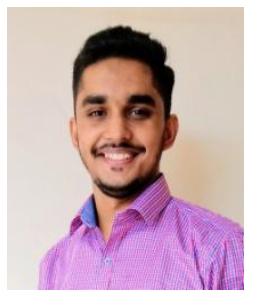

Parth Indraprakash Chhabra, Research Scholar, P.G. Department of Business Studies, Vallabh Vidynagar, Sardar Patel University - Anand

Citation: Mr. Parth I. Chhabra. "Performance Appraisal System: New Horizons" International Journal of Managerial Studies and Research (IJMSR), vol 9, no. 10, 2021, pp. 13-17. doi: https://doi.org/10.20431/23490349.0910003.

Copyright: () 2021 Authors. This is an open-access article distributed under the terms of the Creative Commons Attribution License, which permits unrestricted use, distribution, and reproduction in any medium, provided the original author and source are credited. 